\title{
Willingness to Pay and Inclusive Tariff Designs for Improved Water Supply Services in Urban Bangladesh
}

\author{
Herath Gunatilake ${ }^{1} \&$ Masayuki Tachiri ${ }^{2}$ \\ ${ }^{1}$ Lead Energy Economist, South Asia Department, Asian Development Bank, Manila, Philippines \\ ${ }^{2}$ Senior Economist, Strategy and Policy Department, Asian Development Bank, Manila, Philippines \\ Correspondence: Herath Gunatilake, Asian Development Bank, Manila, Philippines. Tel: 632-632-5468. E-mail: \\ hgunatilake@adb.org
}

Received: December 27, 2013 Accepted: July 3, 2014 Online Published: September 24, 2014

doi:10.5539/jsd.v7n5p212

URL: http://dx.doi.org/10.5539/jsd.v7n5p212

The opinions reflected in this article do not represent the views or policies of Asian Development Bank

\begin{abstract}
The study investigates willingness to pay for improved water supply services in urban Bangladesh, using a contingent valuation survey of 3000 households in Khulna city. Since the large connection cost is regarded as one of the major obstacles to expand the piped network among the poor, the study explicitly incorporates the connection cost in addition to monthly charge. The construct validity tests show that the respondents have understood the elicitation questions and answered truthfully. Policy simulations show that poor households are less likely to be connected under fixed charge tariff, and introduction of volumetric tariff will increase the acceptance of the improved water service by poor households. Increasing block tariff shows the highest uptake rate of the improved service by the poor. The large connection cost is found to be a critical bottleneck to expanding the coverage for the poor. Easy payments systems for connection charge such as installment payments, or including the connection costs under the capital investment of the project, will significantly improve the inclusion of the poor in the proposed water supply scheme.
\end{abstract}

Keywords: household water supply, willingness to pay, contingent valuation, water tariff, Bangladesh

\section{Introduction}

Bangladesh is densely populated country with a growing population. Of the 161 million total population, about $28 \%$ lives in urban areas. Urban population is projected to grow at about $3 \%$ per year. According to the United Nations Children's Fund (UNICEF, 2011) about 36 million people lacks safe drinking water and about 76 million people lacks proper sanitation. Diarrheal diseases constitute a major health problem in Bangladesh, killing over 100,000 children each year. About $85 \%$ of the population is said to have access to an improved source of water but in reality only $20 \%$ of the households have access to a pipe water connection. Over 7 million people live in slum areas and population in slum areas are growing. Bangladesh faces many challenges due to rapid and unplanned urbanization, foremost is the supplying of proper water and sanitation services to growing urban populations. An estimated $\$ 2.36$ billion investment during $2010-1015$ is required to provide proper water supply in urban Bangladesh. Majority of this requirement has to be borrowed from external sources and cost recovery is a key issue that determines financial sustainability of water utilities in Bangladesh.

This study was conducted as part of the preparation of the Khulna Water Supply Project financed by Asian Development Bank (ADB). The project aims to improve the access to safe water through the piped network in Khulna City, Bangladesh. Khulna City is the third largest city in Bangladesh with a population of approximately 1 million. Citizens in Khulna City have been suffering from limited access to water supply services. According to a consumer survey undertaken as a part of the project preparatory studies, only $22 \%$ of the population has access to piped water supply. Households without connection to the network rely on private or shared tube wells built with hand pumps (Figure 1). Even the households connected to the piped network enjoy only intermittent water supply (5.3 hours per day on average), and $74 \%$ of households find the supplied quantity is insufficient. Consequently, households that are connected to the network also use shared tube wells with hand pumps. As for water quality, $59 \%$ of the surveyed households perceived the supplied water to be dirty, and $55 \%$ rated the 
service standards as very poor or poor. Only $11 \%$ of the surveyed households perceived the service standards as good.

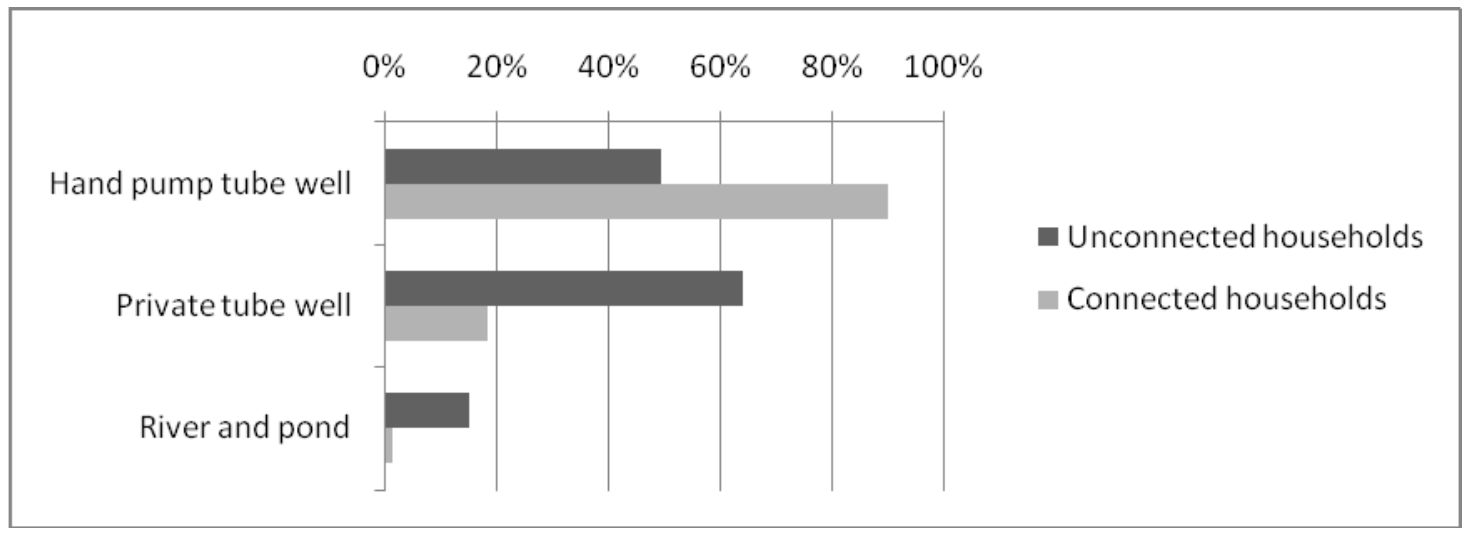

Figure 1. Source of water in Khulna

Source: Consumer survey for Khulna Water Supply Project (2009)

This study was undertaken partly to understand the benefits of improved water services. Since there is no existing market for improved water services, stated preference methods that interview households directly to estimate willingness to pay (WTP) is the most suitable way to estimate the benefits. The current water tariff in Khulna City is a flat rate tariff, which does not recover the costs of existing water service. Adjustment of the tariff structure is necessary to expand and sustain the water supply services. Impacts of an alternative tariff structure are heterogeneous across households, and detailed assessment is necessary to make the new water supply more inclusive for different income groups. In addition to assessing economic viability of projects WTP studies provide valuable information for setting affordable tariff, evaluating policy alternatives, assessing financial sustainability of water utilities, and designing socially equitable subsidies (Brookshire \& Whittington, 1993; Whittington, 2002; Carson, 2003; Gunatilake, Yang, Pattanayak, \& van den Berg, 2006; van den Berg, Pattanayak, Yang, \& Gunatilake, 2006). These value additions of WTP studies form other motivations of the study.

\section{Literature Review}

This study uses contingent valuation (CV) methods to estimate the WTP of urban households in Khulna to get 24 hours of good quality water with accurate billing and good customer service. Contingent valuation method is often used for estimating WTP for non-marketed goods. Goods that are exchanged in market can be valued using revealed preference methods. Economists generally prefer these methods given the inherent difficulties involved in estimating economic values through surveys. Water is supplied in regulated markets and the prices are either distorted or they don't exist. Hence, available prices for urban water services may not necessarily reveal true preferences of households. Moreover, the prevailing distorted prices, when they do exist, do not reflect the benefits of service improvements. Therefore, revealed preference methods are not suitable to estimate the benefits of water service improvements. On the other hand contingent valuation method is flexible and allows description of service improvement to water users, thereby enables estimation of WTP for service improvements.

The literature on contingent valuation is vast and a complete review is beyond the scope of this paper, only selected most relevant literature is cited in the paper. Carson (2012) provides a comprehensive review on literature on contingent valuation referring to 7,500 papers from 130 countries. The first recorded contingent valuation study was conducted in 1963 by Davis, who independently conceived the idea of using surveys to value public goods (Mitchell \& Carson, 1989). Davis (1963) study estimates the benefits of outdoor recreation in the Maine woods in United States. The next major study appears to have been conducted in 1969 (Hammack \& Brown, 1974). The long silence since the introduction of the concept in 1947 by Ciriacy-Wantrup may be due to Samuelson's (1954) argument that free riding and strategic behavior make it difficult to obtain reliable values of individual preferences for public goods through surveys. Despite criticism about the method, which exists even today, the contingent valuation method (CVM) has gained widespread popularity, and there is now a large amount of documented evidence on the use of contingent valuation to derive the welfare assessment of environmental quality changes. Arrow, Solow, Leamer, Radner and Schuman (1993) provided cautiously optimistic view on the use of CVM for environmental valuation, which provided some reassurance for the 
practitioners. The empirical application of CVM has grown rapidly after the publication of this National Oceanic and Atmospheric Administration (NOAA) report.

Of the pioneering work on contingent valuation, Mitchell and Carson (1989) provided a good understanding of the methodology. A comprehensive discussion of theoretical foundations and empirical application of CVM is given by Carson and Hanemann (2005), Shogren (2005), Champ, Boyle and Brown (2003), and Hensher, Rose, and Green (2005). On the empirical application of CVM, Whittington (1998 and 2002) undertook number of studies to acclimatize the CVM in developing countries. His work showed the applicability of the CVM for low income and poorly educated households in developing countries and helped popularizing the application of CVM in developing countries. Gunatilake, Yang, Pattanayak, \& van den Berg, 2006 (2007) describe useful good practices for the application of CVM in water supply and sanitation sector in developing countries.

The earlier contingent valuation studies generally estimated use values but as the theory of nonuse values developed contingent valuation was extended to estimate nonuse values as well (Randall 1987, Randall, Ives, \& Eastman, 1974). Initially, many authors attempted to measure the components of nonuse values separately, but recent emphasis has been on measuring the total economic value, which is usually more relevant for decision-making purposes. However, there is some doubt regarding individuals' ability to differentiate between the components of nonmarket goods (Cummings, Harrison, \& Rutsrom, 1995). This led to the belief among some applicants that contingent valuation may be more accurate if the questions are on total economic value rather than on separated use and nonuse values.

Since the early 1970s, the CVM has been used to measure the benefits of a wide range of environmental goods (Mitchell \& Carson, 1989), including recreation, amenity value, scenery, wetlands, air and water quality, forest and wildlife conservation, etc. Early contingent valuation studies related to species include big game hunting in the Maine woods (Davis, 1963), water-fowl hunting in North America (Hammack \& Brown, 1974), hunting Canadian geese (Bishop \& Heberlein, 1979), the value of viewing whooping cranes (Stoll \& Johnson, 1984), and the opinion and existence values for grizzly bear and bighorn sheep populations (Brookshire, Eubanks, \& Randall, 1983). Application of CVM is spreading beyond the conventional environmental goods. For example, Damigos, Tourkolias, and Diakoulaki (2009) use this method to assess WTP for energy security, O'Garra, et al. (2007) for hydrogen buses, Banfi, Farsi, Filippini, and Jakob (2008) for energy saving measures, Borchers, Duke, and Parsons (2007) for different green energy sources, MacKerron, Egerton, Gaskell, Parpia, and Mourato (2009) for carbon offset certificates, Gunatilake and Raihan (2013) for solar powered water pumping for irrigation, Streimikiené, and Balezentis (2014) for renewable energy, van Putten, Lijesen, Ozel, Vink, and Wevers, (2014) for micro generation of renewable energy by households, Woo (2014) for reducing emissions from coal fired power plants, and Taneja, Pal, Joshi, Aggarwal, and Tyagi (2014) for farmers' preferences for climate-smart agriculture, to mention a few.

Most of the published literature on CVM in peer-reviewed journals is on methodological improvements. Many of such articles focus on reducing biases, comparison of different elicitation methods, improving survey methods, improving validity and reliability, statistical and econometric improvements, and application to new areas. A partial list of recent development in the contingent valuation methodology includes giving time for respondents to think before answering the elicitation questions, combining revealed and stated preference data, handling the don't know responses, multiple bound discrete choice models, and contribution games. A major development of the methodology is the conjoint analysis which allows valuation of the service attributes separately (Adomowics, Louviere, and Williams, 1994; Alpizar, Caarlsson and Martinsson, 2003). Conjoint analysis is becoming increasingly popular. Yang et.al (2006) applies conjoint analysis to value service attributes of water supply improvement in South-West Sri Lanka.

There are a large number of CV studies in the water sector in Asia. Many such studies are, however, undertaken for policy purposes and are not published in academic journals. The published studies of WTP for improved water services in South Asia include Altaf, Jamal, and Whittington (1992), Haq, Usman, and Ahmad (2007), Akter (2008) and Akram and Olmstead (2011) for Pakistan, Islam, Kitawaki, and Rahman (1994), Chowdhury (1999), Ahmad, Goldar, Jakariya, and Misra (2002) for Bangladesh, Venkatachalam (2006) and Guha (2007) for India, Whittington, Pattanaak, Yan, and Kumar (2002) for Nepal, and Gunatilake, Yang, Pattanayak, \& van den Berg, (2006) for Sri Lanka. Amongst the other CV studies in Asia, Calderon et.al (2006) assesses the WTP for improved watershed management in relation to water supply quality improvement in Manila, Wang, Xie and Li (2010) assesses WTP for water supply service in Chongqing, China and Lee, Yoo, and Kim (2013) estimate the WTP for water supply service in Korea. Other published CV studies in water supply sector includes Jordan, and Enlagheeb (1993) for Georgia, Koss and Khawaja (2001) for California, Casey, Khan and Rivas (2006) for Brazil, Soto and Bateman (2006) for Mexico City, Atkins, Burdon and Allen (2007) for Denmark, Kanyoka, 
Farolfi and Morardet (2008) for South Africa, Vásquez, Mozumder, Hernández-Arce and Berrens (2009) for Mexico, Mugabi and Kayaga (2010) for Uganda, and Ramajo-Hernandez and Saz-Salazar (2012) for Spain. As pointed out by many researchers, WTP for improved water services varies from site to site and even from time to time. Therefore, it is necessary to undertake new studies for important policy purposes.

\section{Survey and Estimation Models}

\subsection{Survey}

A household survey covering 3,000 households was conducted in the second quarter of 2009. The sample included both connected and unconnected households; about 1,000 households connected to the piped network and 2,000 households not connected to the network. Khulna City is composed of 31 wards and each ward is divided into several subdivisions, named mohallas. A stratified random sampling procedure was used to develop the sampling frame. Eleven wards were first randomly selected in the city, and 3-4 mohallas were selected from each ward using random number tables. Sample households were chosen by taking the fifth house along streets in chosen mohallas. In the absence of a complete list of households together with the household addresses, this sampling method provided a pragmatic way to select a representative sample.

The survey instrument was developed based on a similar instrument applied in Sri Lanka and Nepal. Focus group discussions were conducted to understand the water situation in Khulna to modify the initial instrument. Questions and multiple-choice responses were prepared and refined through focus group discussions and pretesting. About 100 households were interviewed in pretests. Based on the results of pretests, some questions were rephrased, and the initial bid distribution was refined. The survey includes household characteristics (income, expenditures, employment status, and others); availability and use of public services (piped/non-piped water supply, sanitation, and solid waste management); and contingent valuation scenario of piped water services described in the following paragraph. The enumerators were deployed after training and supervised by coordinators. The enumerators were trained particularly to ask elicitation questions in a proper manner. Some respondents were randomly chosen and the records were verified through repeated survey by coordinators. Survey design, enumerator training, and survey implementation closely followed the good practices recommended in Gunatilake, Yang, Pattanayak, \& van den Berg, 2006 (2007) (2007).

During the survey, households which were not connected to the piped network were asked whether they were willing to connect to the network by paying a certain monthly charge and a one-time connection cost. The level of the monthly charge and the connection cost (bids) were randomly assigned to each household covered under the survey. The monthly charges used in the survey were $100,200,300,400$, or 500 taka (Tk); and the connection cost were Tk1000, Tk3000, or Tk5000.

The respondents were informed about the contingent scenario: by paying these charges, they will have continuous and sufficient water supply with sufficient pressure, and the water will be of good quality, potable without boiling or any other treatment. The respondents were provided sufficiently detailed information by enumerators, as summarized below:

"With the population growing, the government foresees that the water supply situation in the city will worsen in the next years if no intervention is made soon to address the situation. The Government has established the Khulna Water and Sewerage Authority (KWASA) and is preparing a project to improve water supply services in Khulna. The proposed project will involve sourcing raw water from the river to meet the water demand of households and business enterprises. Water will be treated to make it safe for human consumption. This means sufficient water will be made available to the household, water will be safe to drink from the tap, and therefore will not need boiling, filtering, or treating. Water will be available 24 hours a day with sufficient water pressure, so there would be no need to store water. There will be no need to go to public tube wells to fetch the water or build private tube wells. It is expected that the proposed improvements will reduce incidences of water-related diseases due to poor water quality and hygiene. KWASA will manage the new water supply system with enhanced customer service, such as more efficient billing and collection and more responsive customer services.

Now, I want you to assume that the improved water service would be provided by KWASA if you pay certain charges. The proposed amount is not the planned tariff, and we try to assess the values of the improved water services. If you had to pay ---------- taka per month per family and in addition you need to pay a one-time cost to make connection of approximately ----------- taka, would you like to get a connection and pay the monthly bills?" 
The question mimics the actual decision that households face: the household will decide whether they would connect to the network in order to obtain the proposed water supply services by paying proposed charges. It is important that respondents were asked whether they would connect or not by paying the proposed charges, rather than asking an open-ended question like how much they would pay for the proposed services. Households cannot decide the amount of payments in reality, since answering an open-ended question requires very high cognitive demand. For households which already have a connection with the network, they were asked whether they would like to remain connected to improve the service standard by paying higher monthly charges.

\subsection{Estimation Model}

Most studies focus exclusively on monthly charge and do not explicitly address the issue of connection cost. Their models of WTP estimation for the monthly charge are shown as model (A). Based on a probability model such as probit or logit, $(1 / \sigma)$ and $(\beta / \sigma)$ are estimated, which then identify $\beta$ and $\sigma$. With the estimated $\beta$, willingness to pay can be estimated for each household by WTP $=\exp (X \beta)$.

(A) Prob ( $\mathrm{D}=1$ if household is willing to connect by paying the monthly charge (bid price))

$$
\begin{aligned}
\quad=\operatorname{Prob}(\mathrm{WTP}>\text { bid }) \\
=\operatorname{Prob}(\exp (\mathrm{X} \beta+\varepsilon)>\text { bid }) \\
=\operatorname{Prob}(\mathrm{z}>(\log (\text { bid })-\mathrm{X} \beta) / \sigma)),
\end{aligned}
$$

where D: Dummy variable to indicate the household is willing to connect or not

WTP: Willingness to pay

$\mathrm{X}$ : Vector of household attributes

$\beta$ : Vector of coefficients

$\varepsilon$ : Error term with mean zero and variance $\sigma^{2}$

z: Normalized error term

The conventional model (A) is extended under this study to explicitly incorporate the connection cost, since the one-time connection charge is often regarded as one of the biggest constraints to expand connections, especially for the poor households (ADB, 2003; Komives, Foster, Halpern, \& Wodon, 2005).

(B) Prob $\left(\mathrm{D}_{\mathrm{b}}=1\right.$ : willing to connect by paying monthly charge,

$\mathrm{D}_{\mathrm{c}}=1$ : willing to connect by paying connection cost)

$$
=\operatorname{Prob}\left(\mathrm{WTP}_{\mathrm{b}}>\operatorname{bid}_{\mathrm{b}}, \mathrm{WTP}_{\mathrm{c}}>\operatorname{bid}_{\mathrm{c}}\right)
$$

$$
=\operatorname{Prob}\left(\exp \left(\mathrm{X} \beta_{\mathrm{b}}+\varepsilon_{\mathrm{b}}\right)>\operatorname{bid}_{\mathrm{b}}, \exp \left(\mathrm{X} \beta_{\mathrm{c}}+\varepsilon_{\mathrm{c}}\right)>\operatorname{bid}_{\mathrm{c}}\right)
$$

$$
=\operatorname{Prob}\left(\mathrm{z}_{\mathrm{b}}>\left(\log \left(\mathrm{bid}_{\mathrm{b}}\right)-\mathrm{X} \beta_{\mathrm{b}}\right) / \sigma_{\mathrm{b}}, \mathrm{z}_{\mathrm{c}}>\left(\log \left(\mathrm{bid}_{\mathrm{c}}\right)-\mathrm{X} \beta_{\mathrm{c}}\right) / \sigma_{\mathrm{c}}\right)
$$

The extended model $(\mathrm{B})$ assumes $\left(\varepsilon_{\mathrm{b}}, \varepsilon_{\mathrm{c}}\right)$ follows a bivariate normal distribution. It is unlikely that $\left(\varepsilon_{\mathrm{b}}, \varepsilon_{\mathrm{c}}\right)$ are distributed independently, and the bivariate probit model can accommodate the correlation between $\varepsilon_{\mathrm{b}}$ and $\varepsilon_{\mathrm{c} .}$. By running a bivariate probit regression, the coefficients $\left(1 / \sigma_{b}\right),\left(\beta_{b} / \sigma_{b}\right),\left(1 / \sigma_{c}\right)$, and $\left(\beta_{c} / \sigma_{c}\right)$ are estimated, which are then used to estimate willingness to pay the monthly charge $\left(\mathrm{WTP}_{\mathrm{b}}\right)$ and willingness to pay he connection cost $\left(\mathrm{WTP}_{\mathrm{c}}\right)$. Table 1 summarizes the households' attributes $(\mathrm{X})$ and expected sign of coefficients. 
Table 1. Expected sign of coefficients

\begin{tabular}{|c|c|c|}
\hline $\mathrm{X}$ variables & $\begin{array}{l}\text { Expected } \\
\text { sign }\end{array}$ & Reasons \\
\hline Bid & - & $\begin{array}{l}\text { Households are less likely to connect as water charge rises - } \\
\text { law of demand }\end{array}$ \\
\hline Household expenditure & + & $\begin{array}{l}\text { Expenditure is a proxy for income; the higher the income the } \\
\text { higher the WTP }\end{array}$ \\
\hline Squared household expenditure & - & Diminishing income effect \\
\hline $\begin{array}{l}\text { Household's expenditure on } \\
\text { power }\end{array}$ & + & $\begin{array}{l}\text { Households with more expenditure on other utilities are likely } \\
\text { to accept water charge and obtain connection }\end{array}$ \\
\hline $\begin{array}{l}\text { Dummy variable for household } \\
\text { with private tube wells }\end{array}$ & - & $\begin{array}{l}\text { Households with private water sources are less likely to } \\
\text { connect-substitution effect }\end{array}$ \\
\hline $\begin{array}{l}\text { Schooling year of household } \\
\text { head }\end{array}$ & + & $\begin{array}{l}\text { More educated households are aware of health benefits of } \\
\text { water service and more likely to connect }\end{array}$ \\
\hline $\begin{array}{l}\text { Dummy variable for household } \\
\text { with public hand-pump tube } \\
\text { wells }\end{array}$ & + & $\begin{array}{l}\text { Households using public hand-pump tube wells do not have } \\
\text { good alternative source of water and are more likely to connect } \\
\text { to public water service }\end{array}$ \\
\hline
\end{tabular}

Source: Authors' assessment.

\section{Estimation Results}

Table 2 summarizes the estimated results of model (B). Households' attributes (X) which were found statistically significant at the $5 \%$ confidence level are household expenditure, squared household expenditure, dummy variable for household with private wells, dummy variable for household with hand-pump tube wells, schooling year of household head, and household expenditure for electricity.

Table 2. Estimated coefficients

\begin{tabular}{lcccc}
\hline & \multicolumn{2}{c}{$\begin{array}{c}\mathrm{D}_{\mathrm{b}}=1 \text { : willing to connect by } \\
\text { paying monthly charge }\end{array}$} & \multicolumn{2}{c}{$\begin{array}{c}\mathrm{D}_{\mathrm{c}}=1 \text { : willing to connect by } \\
\text { paying connection cost }\end{array}$} \\
\cline { 2 - 5 } X variables & $\begin{array}{c}\text { Estimated } \\
\text { coefficient }\end{array}$ & Z-value & $\begin{array}{c}\text { Estimated } \\
\text { coefficient }\end{array}$ & Z-value \\
\hline Bid (log) & $(0.54)$ & $(13.25)^{* *}$ & $(0.40)$ & $(12.16)^{* *}$ \\
Household expenditure (log) & 4.51 & $2.85^{* *}$ & 5.47 & $3.58^{* *}$ \\
Squared household expenditure (log) & $(0.22)$ & $(2.54)^{* *}$ & $(0.28)$ & $(3.28)^{* *}$ \\
Household expenditure on power & 0.05 & $5.43^{* *}$ & 0.04 & $4.59^{* *}$ \\
Dummy variable for household with & $(0.38)$ & $(3.94)^{* *}$ & $(0.42)$ & $(4.41)^{* *}$ \\
$\quad$ private tube wells & & & & $3.54^{* *}$ \\
Schooling year of household head & 0.02 & $2.22^{* *}$ & 0.02 & $4.51^{* *}$ \\
Dummy variable for household with & 0.26 & $2.96^{* *}$ & 0.39 & $(3.44)^{* *}$ \\
$\quad$ public hand-pump tube wells & & & & $(23.94)$ \\
Constant term & $(20.02)$ & $(2.78)^{* *}$ & & \\
\hline
\end{tabular}

( ) = negative.

** statistically significant at 0.05 significance level

Source: Authors' estimates. 
All these variables also have the expected signs. Statistical significance and expected signs indicated the construct validity of the elicitation question, i.e., that the respondents have understood the questions and answered truthfully. The households' willingness to pay rises as households become richer. Willingness to pay (WTP) is high if households do not have private tube wells or use public tube wells. More educated household heads are also ready to pay higher charges for water.

The WTP is estimated for each household with the coefficients obtained in the regression. The mean WTP for the monthly charge is estimated at Tk301 per month. The distribution of the estimated WTP is positively skewed, and the median value is Tk229 lower than the mean. The median of the estimated WTP for the one-time connection cost is $\mathrm{Tk} 3,197$.

Figure 2 shows the estimated WTP by households' monthly expenditure decile. Decile 1 is the poorest $10 \%$ households, and decile 10 is the richest $10 \%$ households. The box for each decile shows the range from the first quartile to the third quartile, with the median indicated by a line. As expected, WTP rises along with the level of household expenditure. The median of willingness to pay the monthly charge is Tk124 for the poorest decile of households, while it is Tk303 per month for the richest decile of households. The willingness to pay the one-time connection charge is also higher for richer households (Figure 3). Since WTP is a function of various household attributes, in addition to income, it does not monotonically increase as income increases. This is the reason for the lower median WTP for some higher income deciles.

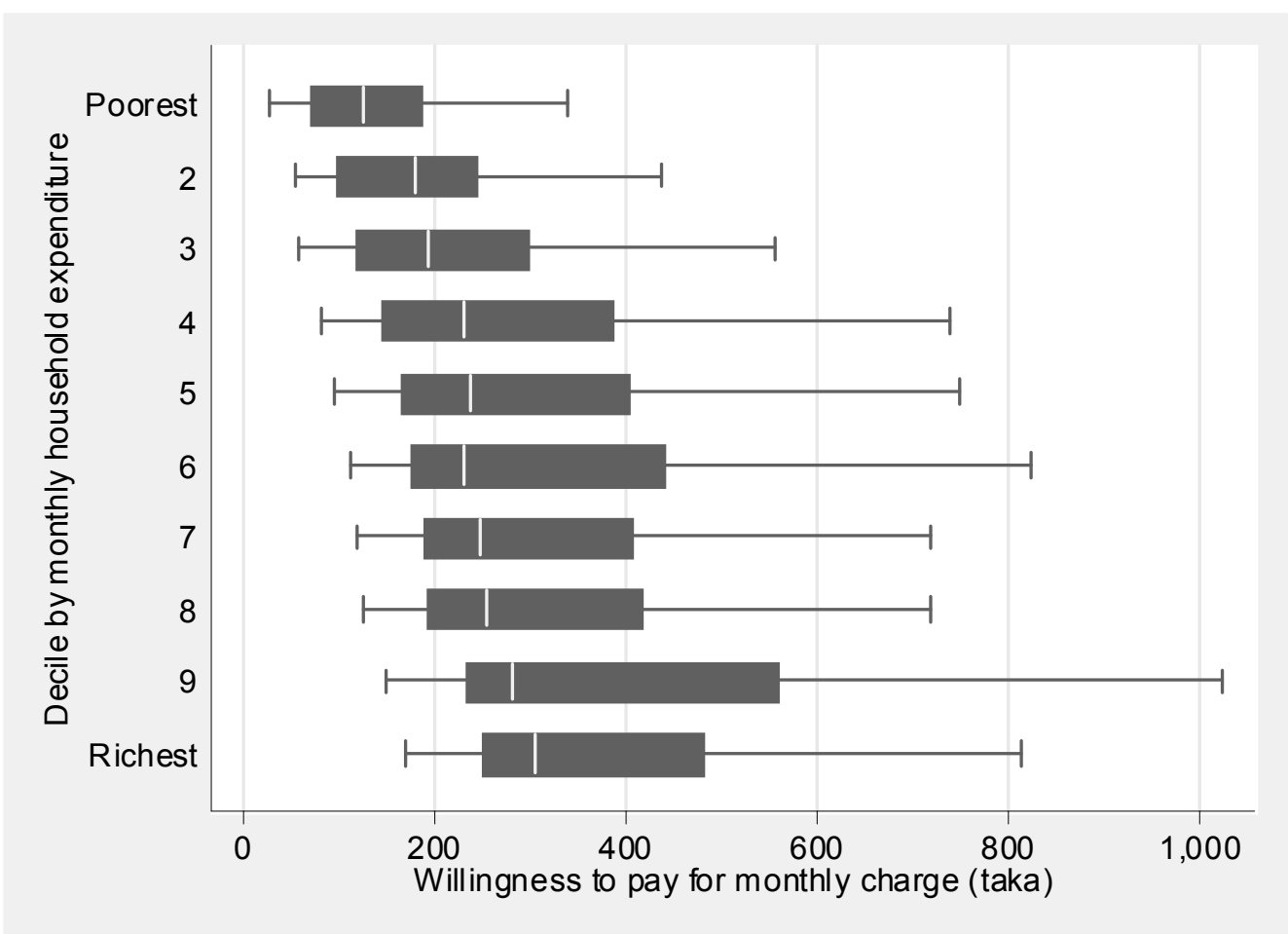

Figure 2. Willingness to pay the monthly charge

Note: Excludes outside values.

Source: Authors' estimates. 


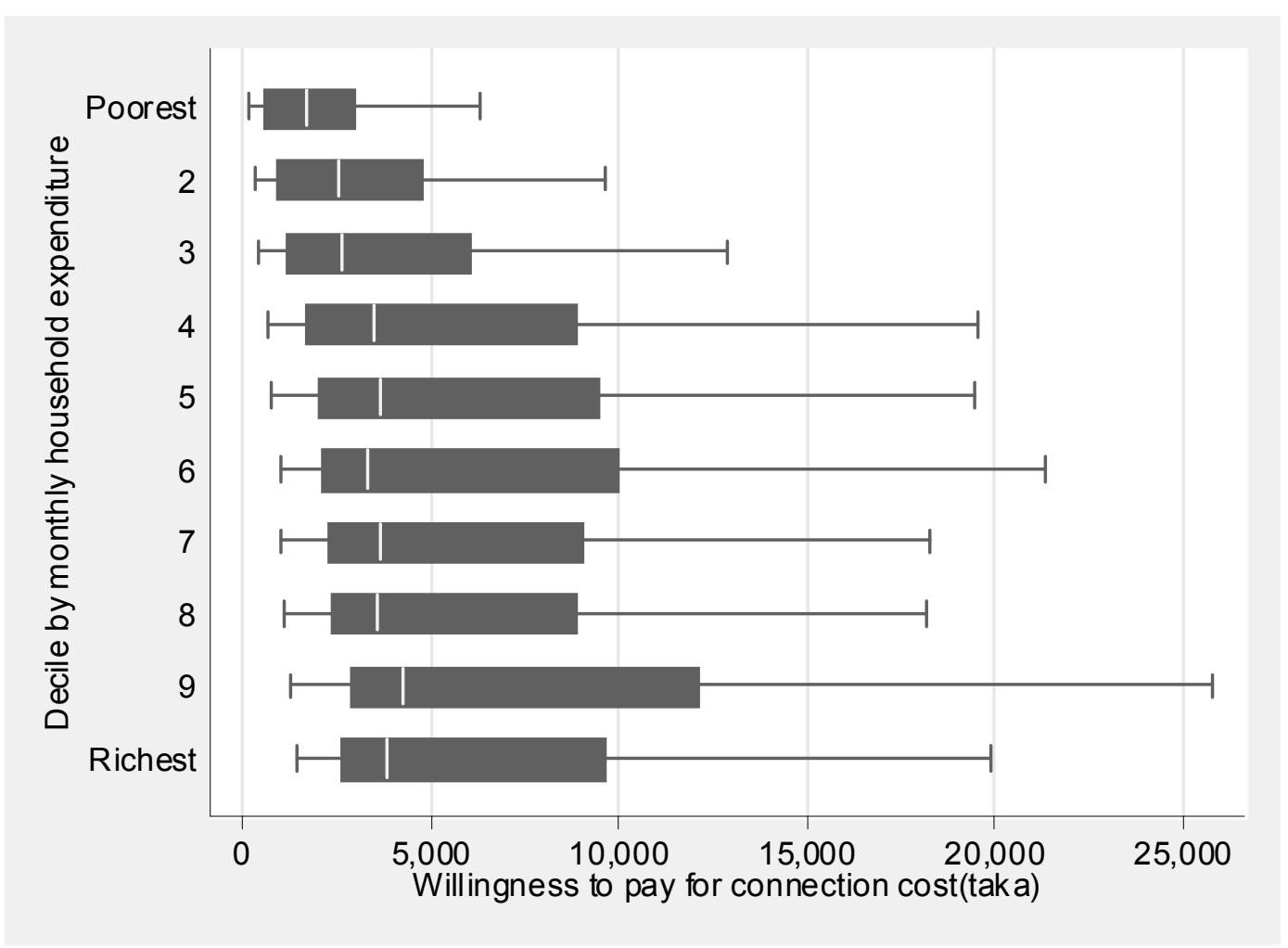

Figure 3. Willingness to pay the connection cost

Note: Excludes outside values.

Source: Authors' estimates

The affordability of the tariff is often assessed in terms of percentage share of monthly household income. Figure 4 shows the willingness to pay the monthly charge as a percentage share of monthly household expenditure. Although the absolute amount of WTP is higher for richer households, the share of household expenditure is higher for the poor households. The median WTP is $3.6 \%$ of expenditure for households in the poorest decile, while it is $1.4 \%$ for households in the richest decile. This shows that the burden of the monthly water bill is higher for poor households. A rule of thumb in setting the water and sewerage tariff is to limit it to $5 \%$ of household income. The median WTP for overall households is $2.5 \%$, close to the rule of thumb, assuming that the sewerage tariff will be equivalent to the water tariff. However, it should be noted here that the WTP indicates the total benefits of improved water service to the household; therefore, the tariff should be lower than WTP. 


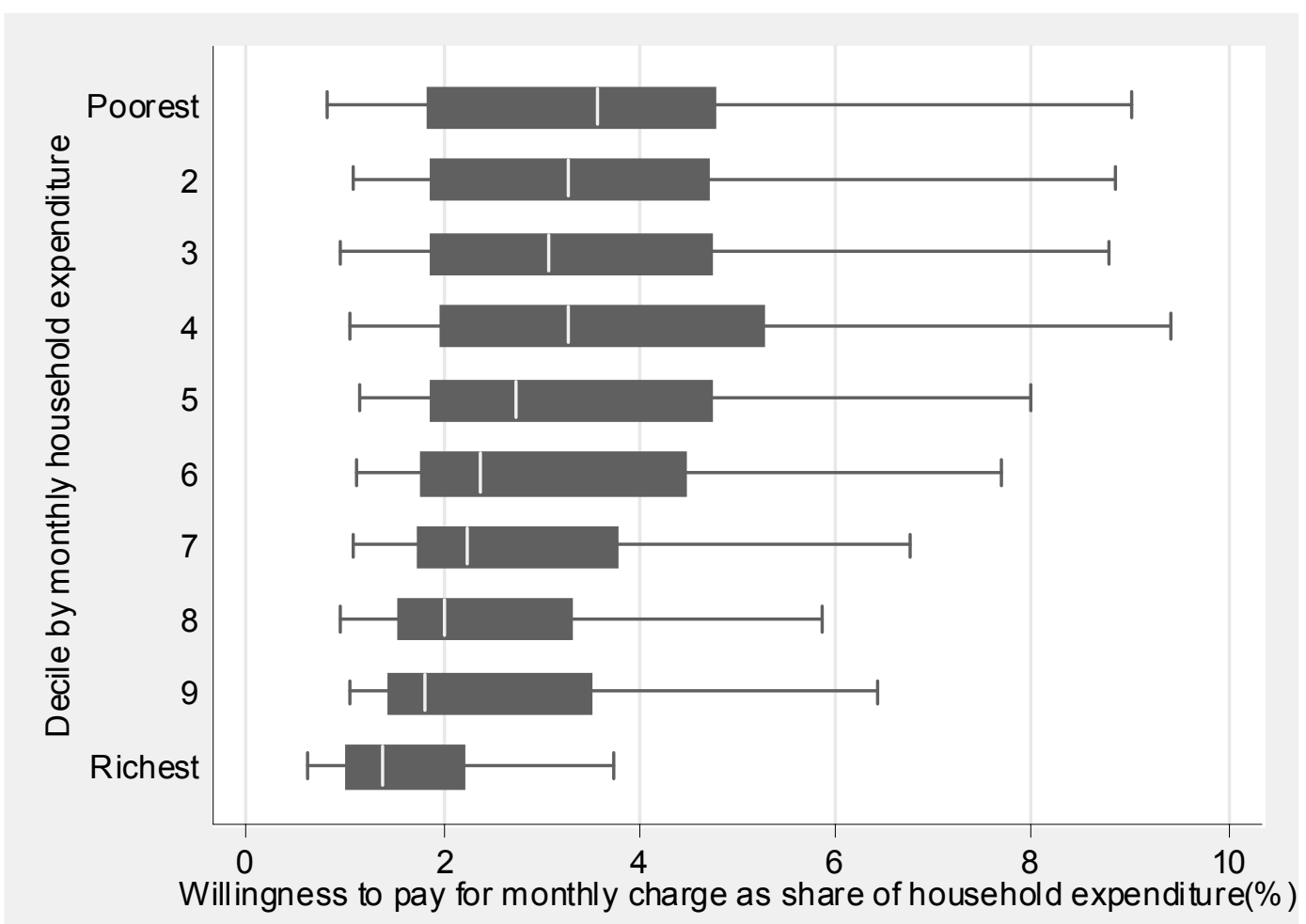

Figure 4. Willingness to pay the monthly charge as share of household expenditure

Source: Author's estimates

Another rule of thumb for water-tariff setting is to keep it around one-third of the expenditure for electricity. Figure 5 shows the relation between the estimated WTP and actual expenditure for power. The estimated WTP is generally higher than one-third of the expenditure for electricity. This result imply that if the tariff is set around one-third of the electricity bill, households are willing and can afford to connect to the water supply services because their willingness to pay for water is generally higher than one-third of the electricity bill. Note, however, that this interpretation is valid only for the current electricity bills and values of other relevant variables. Electricity is heavily subsidized in Bangladesh Gunatilake and Roland-Holst (2013) and if a major revision of electricity prices takes place, this rule of thumb may not work. Therefore the use of the electricity bill to decide on the tariff is pragmatic in Khulna only under the prevailed social and economic status at the time of the survey. 


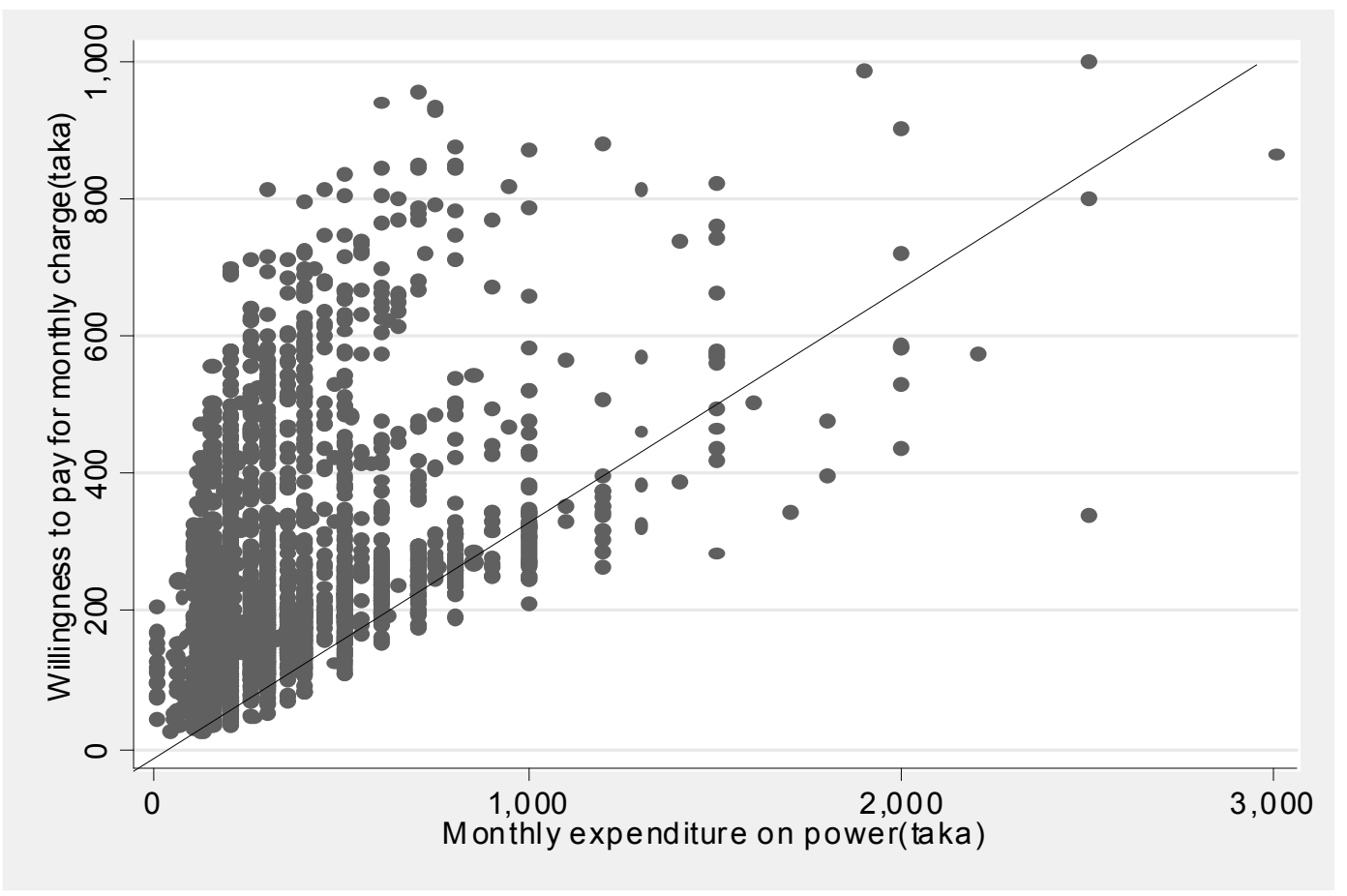

Figure 5. Willingness to pay and expenditure for electricity

Source: Author's estimates.

Besides household expenditure class, other attributes have large impacts on WTP. As expected, households that have a private well expressed lower willingness to pay for water supply services, since they already have an alternative water source. The median willingness to pay of the monthly charge is lower by Tk189 for households with a private well, compared with households without a private well. Households that use public hand-pump tube wells expressed higher WTP, because their alternative water source is generally away from home, and want to switch to piped water services. The median WTP is Tk157 lower for households that do not use hand-pump tube wells, compared with households which use hand-pump tube wells (Figure 6). 

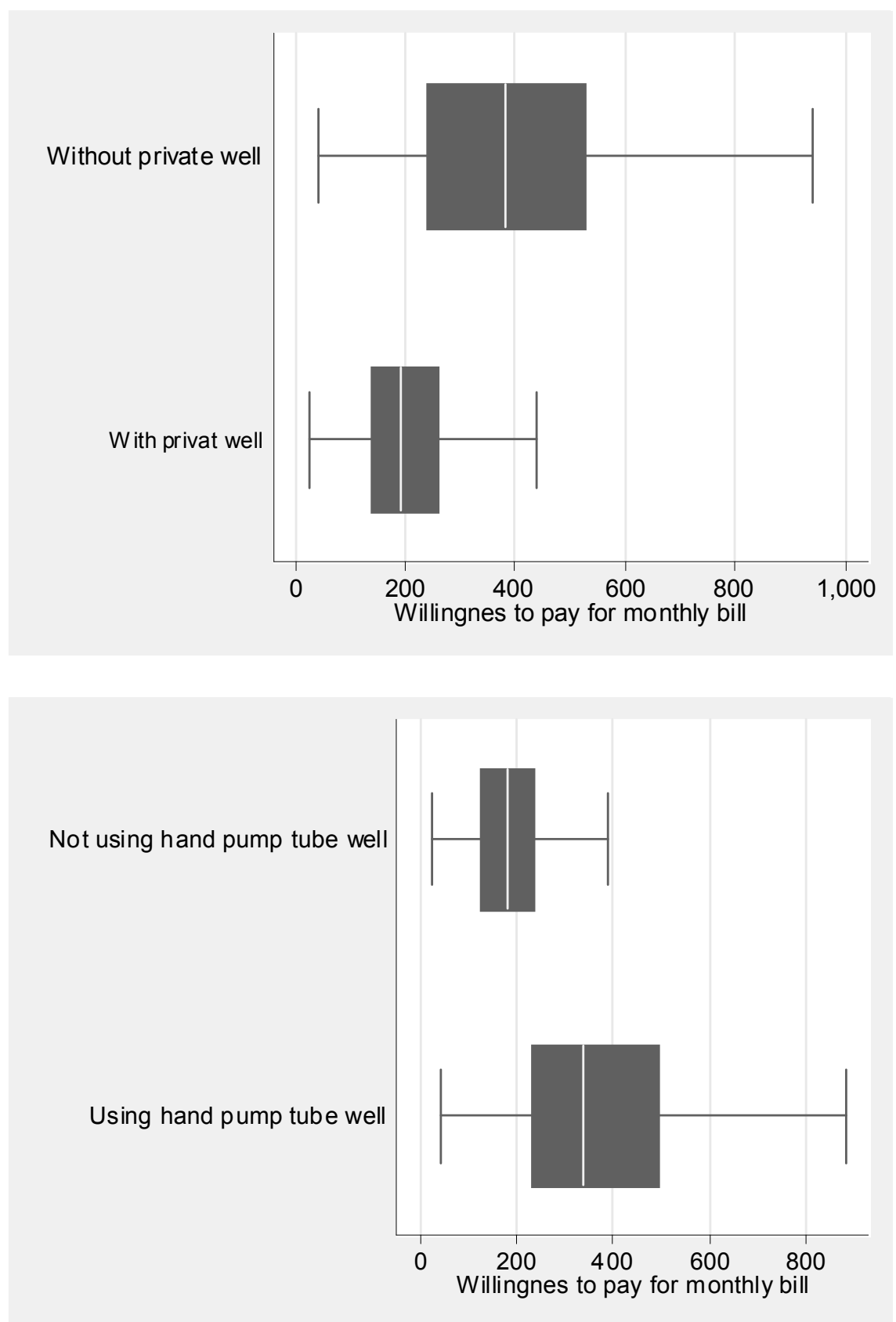

Figure 6. Other attributes affecting willingness to pay

Source: Authors' estimates.

\section{Policy Simulations}

By using the estimated coefficients of the regression model, the likelihood for each household to be connected under various tariff policy options can be estimated. The methodology for predicting the probability is explained in Gunatilake et al. (2007). The predicted connection ratio can be interpreted as the coverage ratio of the piped network for a group of households with the same attributes. Figure 7 shows the estimated likelihood to be connected, under the policy scenario with the monthly fixed charge at Tk100 and one-time connection cost at Tk 1000. As expected, poor households are less likely to be connected than rich households, implying that the coverage of the piped network will be lower among the poor households. Under this scenario, the estimated connection ratio for the poorest decile is $52 \%$, while the connection ratio for the richest decile is $68 \%$. 


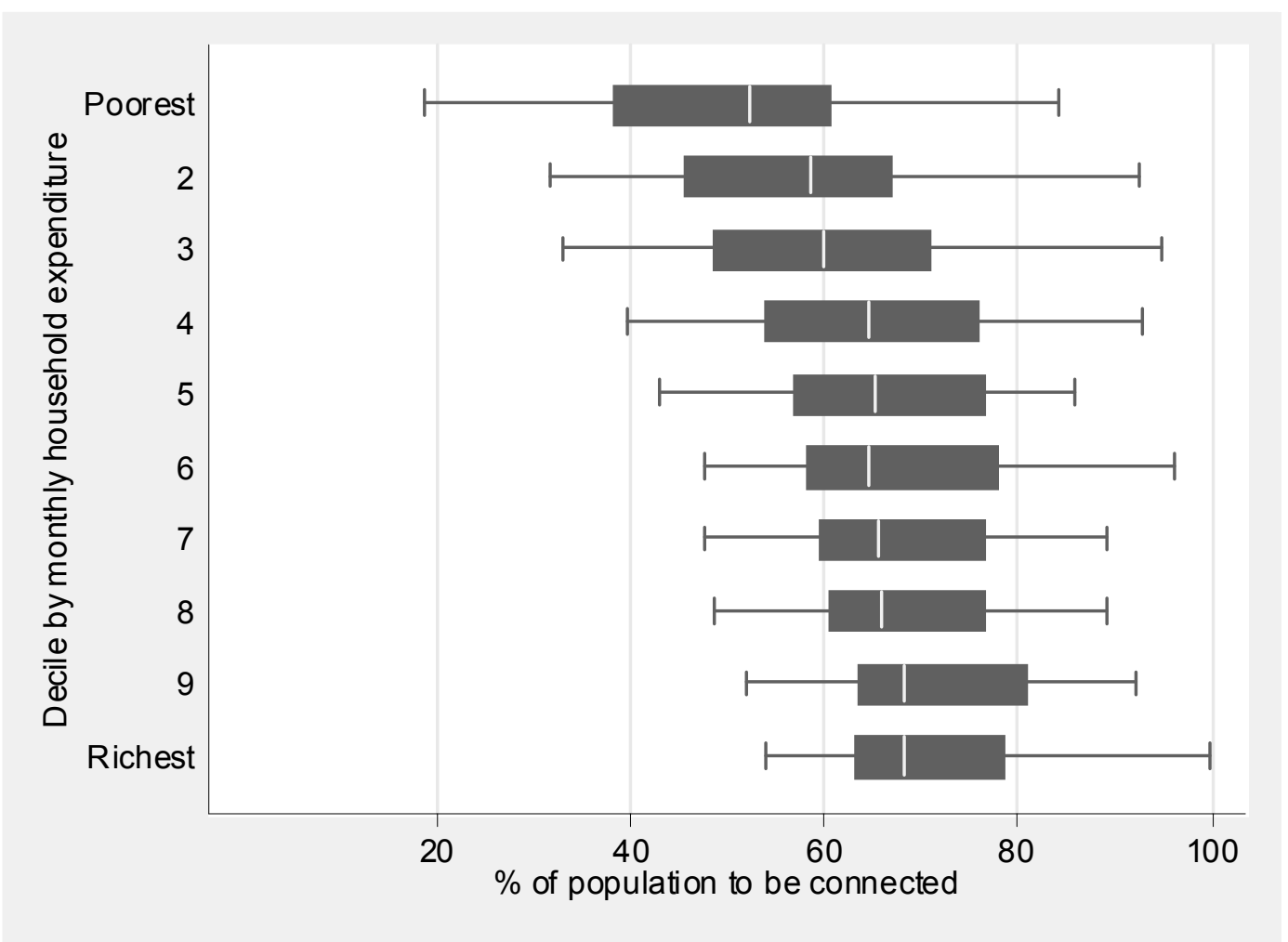

Figure 7. Estimated connection ratio with fixed monthly charges

Source: Authors' estimates.

The fix monthly charge, that is not linked to the quantity of water consume, imposes a disproportionately large financial burden on poor households who use less quantity of water. This type of tariff hampers expansion of the piped network among the poor households. The fix charges may also discourage efficient use and conservation of water. The government plans to introduce a volumetric tariff which will enhance efficient use of water. Figure 8 compares the estimated connection ratio under a flat tariff and volumetric tariff. The flat rate is assumed at Tk100 per month, and the volumetric tariff is assumed at Tk7 per cubic meter $\left(\mathrm{m}^{3}\right)$. The consumption volume of water is assumed at 80 liters per capita per day (lpcd) for the poorest and the second poorest decile of households, $120 \mathrm{lpcd}$ for the richest and the second richest decile, and $100 \mathrm{lpcd}$ for the remaining households. For the median households (100 lpcd), the assumed volumetric tariff is equivalent to the flat rate charge. From Figure 8 , it is clear that volumetric tariff will improve the coverage of poor households. However, the connection ratio under volumetric tariff is lower for rich households. 


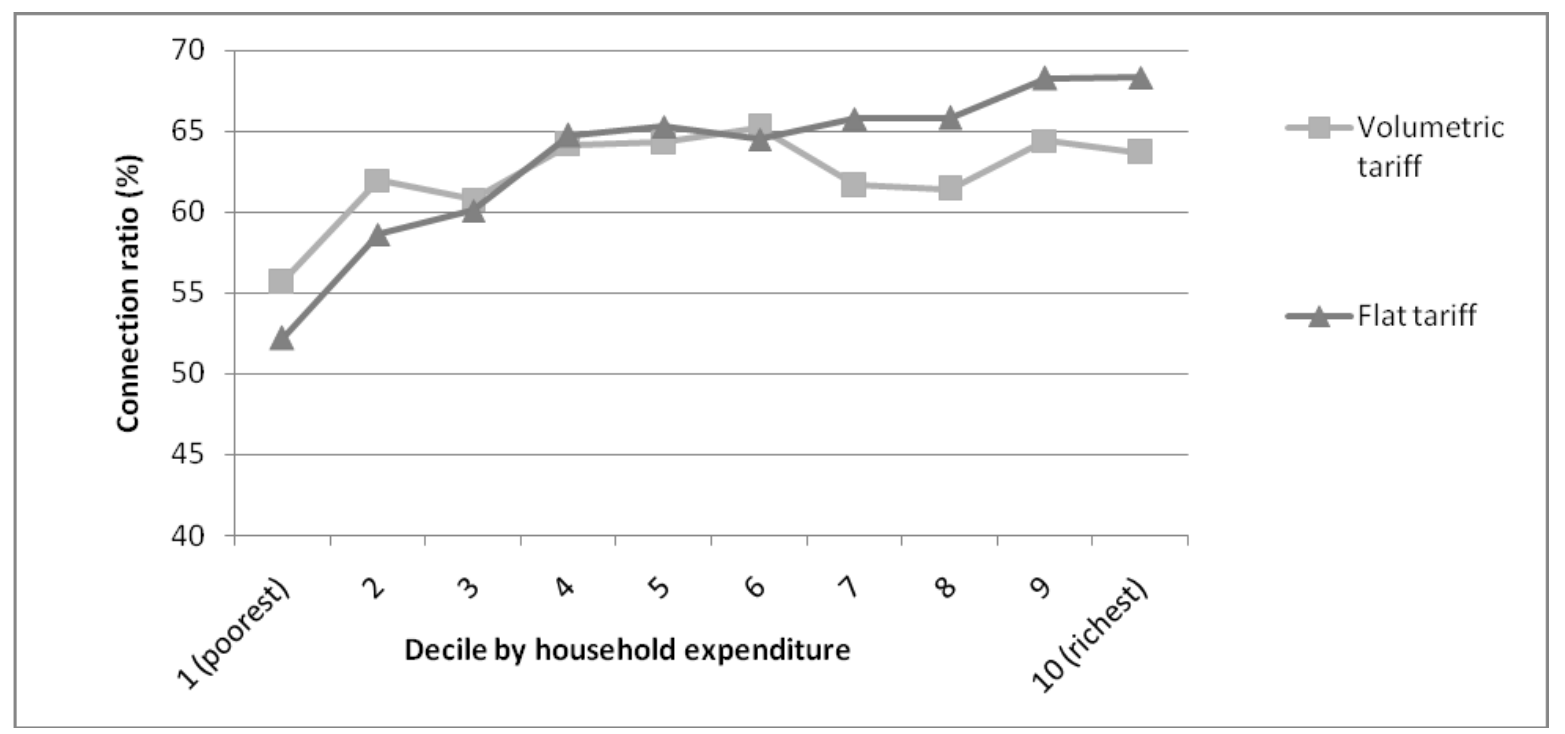

Figure 8. Connection ratio under fix charge tariff and volumetric tariff

Source: Author's estimates.

Figure 9 further adds the connection ratio under an increasing block tariff, which makes the tariff structure even more pro-poor. It is assumed that the volumetric tariff is Tk5 $\mathrm{per} \mathrm{m}^{3}$ for the first $10 \mathrm{~m}^{3}$ of consumption, Tk15 per $\mathrm{m}^{3}$ for $10-15 \mathrm{~m}^{3}$, and Tk20 per $\mathrm{m}^{3}$ for more than $15 \mathrm{~m}^{3}$. The connection ratio for the poor households rises further from the level under the flat volumetric tariff, though the decline of the connection ratio of rich households becomes very large. This result should be interpreted cautiously. The larger bills for rich households make them reject the improved service under block tariff. However, households have the option to reduce their consumption. Rich households may use water for gardening, washing cars etc, in addition to the basic household needs such as drinking, cooking and bathing. Therefore, these households have the option for water conservation to reduce the bills rather than disconnecting the service.

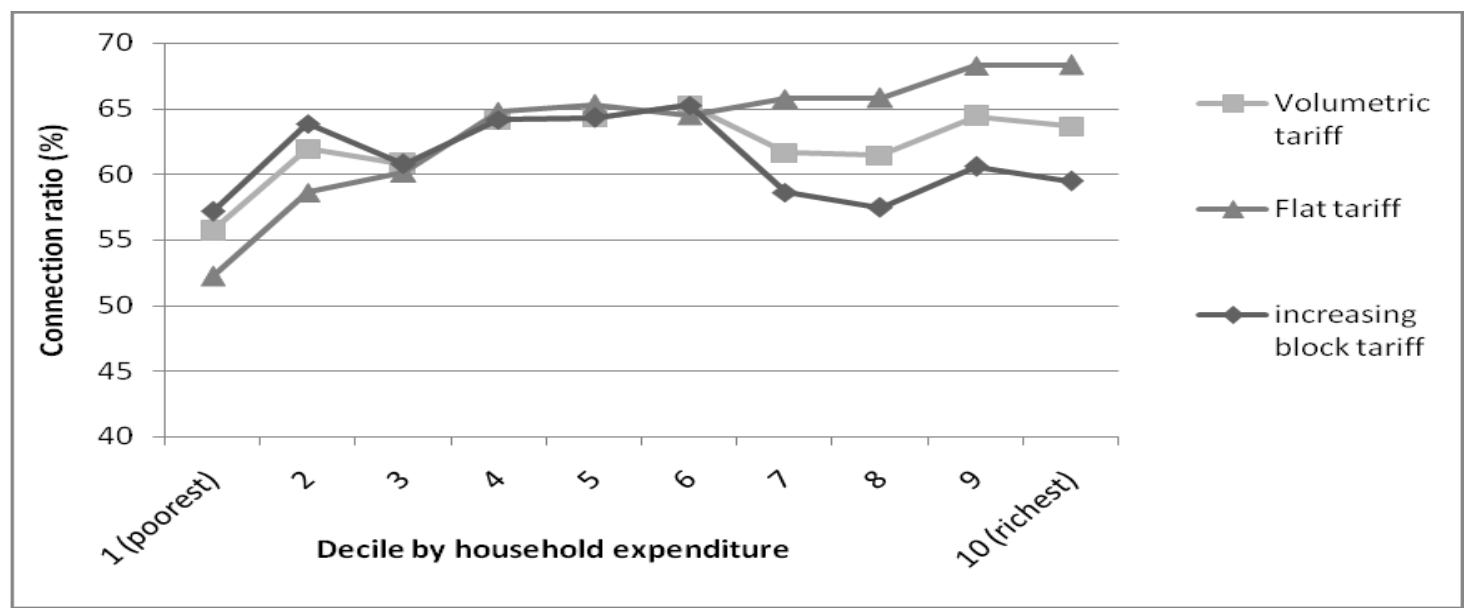

Figure 9. Connection ratio under increasing block tariff

Source: Authors' estimates.

In many cities, households need to pay a large lump sum for a connection. According to ADB (2004), the connection cost in Dhaka was as large as $\$ 29$, which is close to half the monthly expenditures for the poorest quintile of households in Khulna. The large connection cost is commonly regarded as a major obstacle to expanding piped connections, especially among the poor households. Figure 10 shows the impacts of different connection costs, while keeping the monthly charge at $\mathrm{Tk} 7$ per $\mathrm{m}^{3}$. The connection cost has large implications on 
the connection ratio, especially for the poor household. Figure 10 shows the connection ratio does not improve very much for the poor households even with a lower volumetric tariff when connection cost is high. In contrast, Figure 10 also shows that lowering the connection cost substantially improves the connection ratio for the poor. Although the result is subject to the specific local environment and policy parameters, it supports the common notion that the large connection cost hampers the expansion of piped connections among the poor.

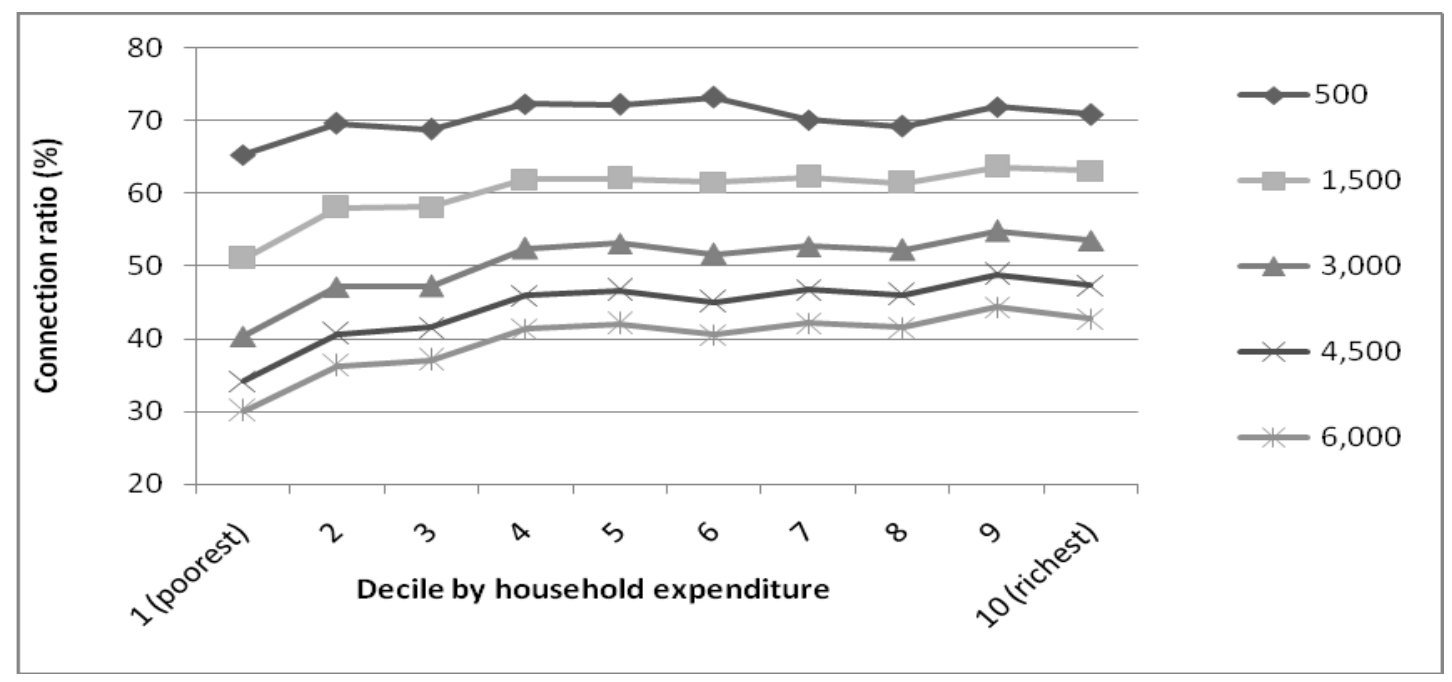

Figure 10. Connection ratio under different connection costs

Source: Authors' estimates.

It will help the poor to lower the connection cost, but the cost needs to be recovered eventually. In order to avoid a large connection cost to be paid at once, some water utilities offer installment payments. If the utility has a project with a large capital investment, the service connection can be included in the project, and the cost can be recovered gradually as part of a capital investment. Figure 12 shows the impacts of such arrangements. The baseline scenario assumes $\mathrm{Tk} 3000$ for the connection cost and $\mathrm{Tk} 5 \mathrm{per} \mathrm{m}^{3}$ for the monthly charge. For installment payments, it is assumed that the connection cost is reduced to Tk500, and the households gradually repay the balance of Tk2500 over 2 years together with the monthly charge. Assuming a real interest rate of 3\%, it is equivalent to additional Tk7.2 for the monthly charge. The figure shows that it does improve the coverage ratio for the poor households. Further, if the capital investment project can absorb the balance of Tk2500, and the capital expenditure is financed by a long-term loan with a tenor of 20 years, the recovery of $T k 2500$ can be made over 20 years. Assuming again a 3\% interest rate, it translates into additional Tk1.0 for the monthly charge. This arrangement will improve the overall connection ratio significantly, in particular for the poor households. 


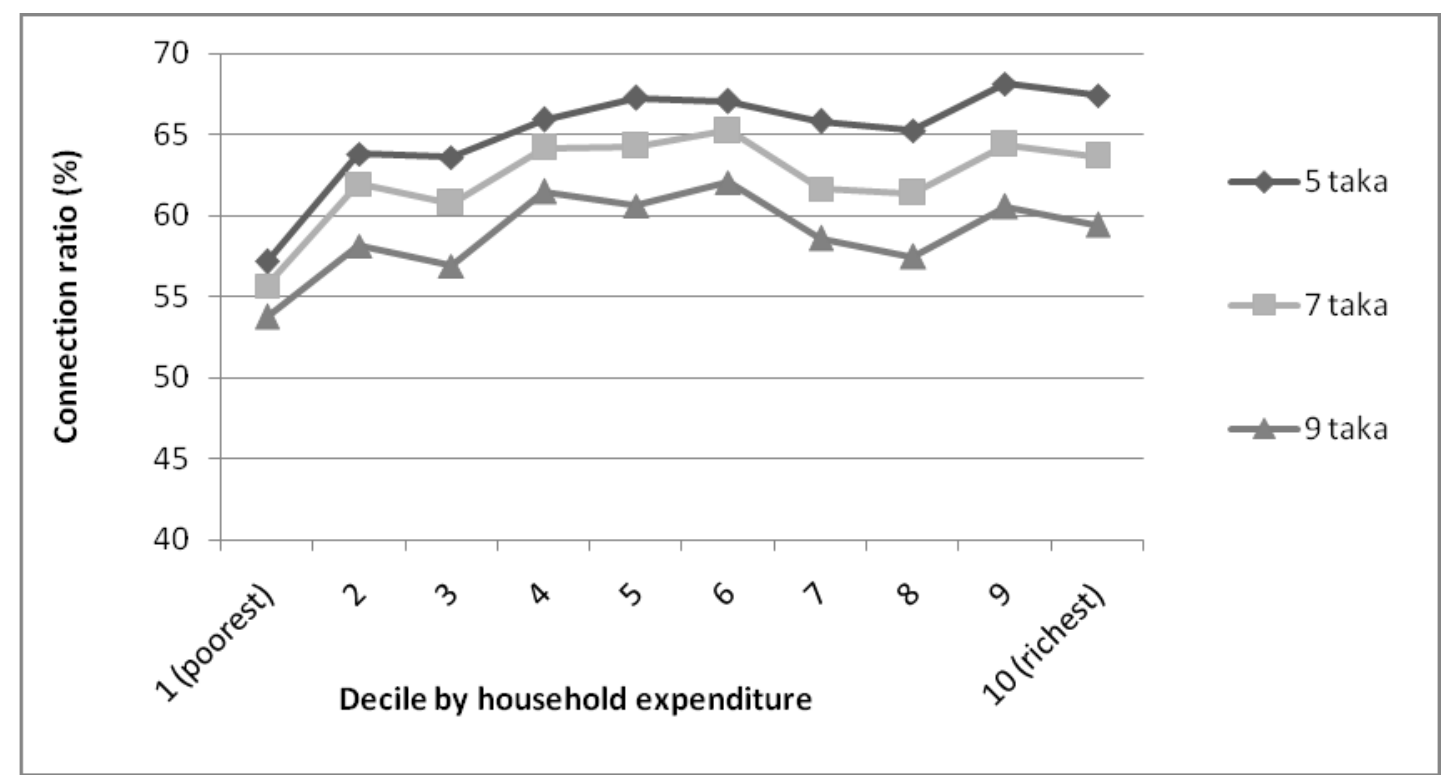

Figure 11. Connection ratio under different volumetric tariffs

Source: Authors' estimates.

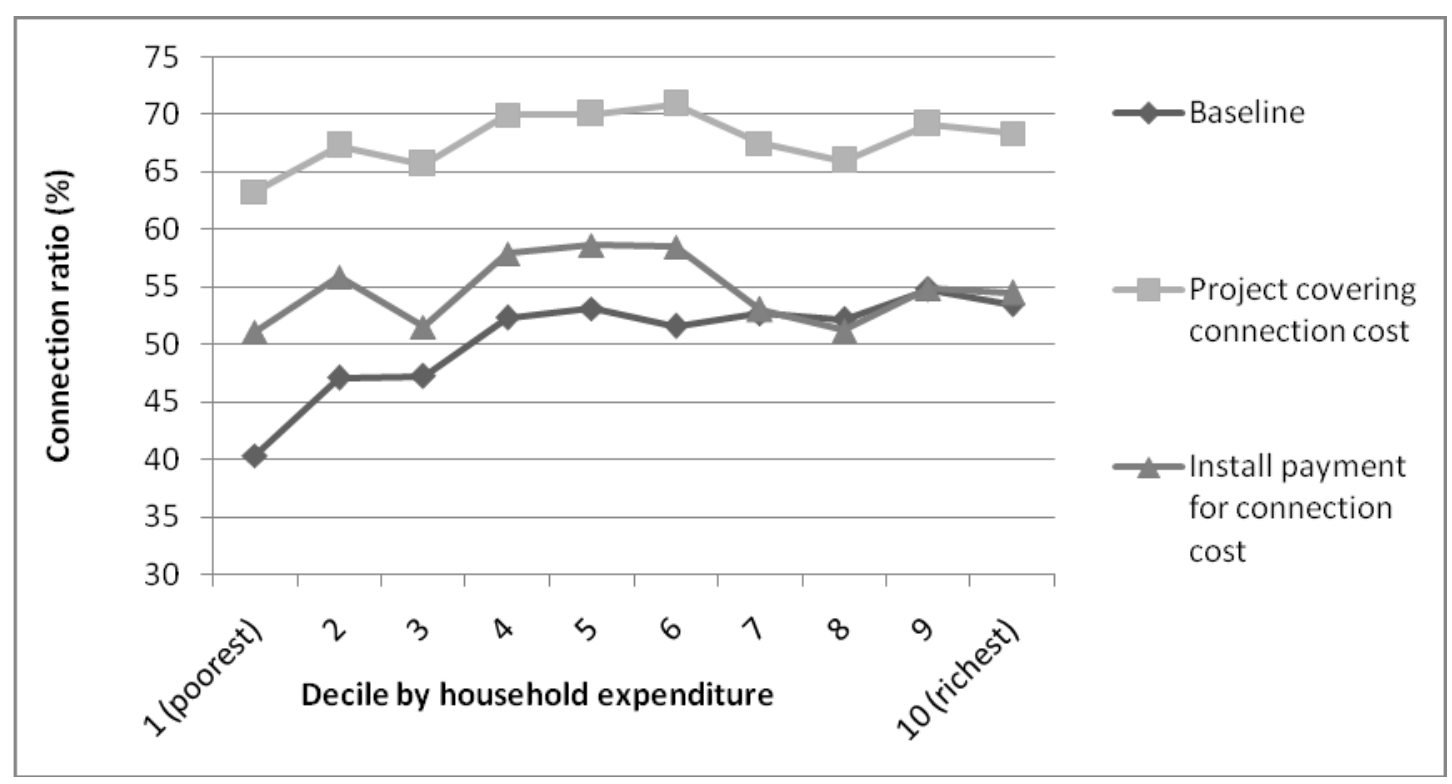

Figure 12. Connection ratio and recovery of connection cost

Source: Authors' estimates.

\section{Conclusion}

This study was undertaken covering 3000 households and was carefully conducted to ensure sound representative sampling and measures to avoid the potential biases of contingent valuation studies. The construct validity tests through regression results confirm that the respondents understood the WTP-eliciting questions and provided reasonable responses. The results show that perceived benefits by households on the improved water services is large enough to justify the project costs. Policy simulations show that volumetric tariffs are pro-poor and block tariffs further improve the inclusiveness of the poor. Higher connection charges, as common in many water supply projects, are a barrier to poor households to access improved water services. Easy financing methods for connection charges are required to ensure poor households' access to improved water services. 


\section{References}

Adamowicz, W., Louviere, J., \& Williams, M. (1994). Combining Revealed and Stated Preference Methods for Valuing Environmental Amenities. Journal of Environmental Economics and Management, 26, 271-292. http://dx.doi.org/10.1006/jeem.1994.1017

ADB. (2003). Asian water supplies, reaching the urban poor. Manila: ADB.

ADB. (2004). Water in Asian cities, utilities' performance and civil society views. Manila: ADB.

Ahmad, J. K., Goldar, B. N., Jakariya, M., \& Misra, S. (2002). Willingness to pay for Arsenic-free, safe drinking water in rural Bangladesh - methodology and results. Water and Sanitation Program WSP-SA.

Akram, A., \& Olmstead, S. M. (2011). The value of household water service quality in Lahore, Pakistan. Environmental Resource Economics, 49, 173-198. http://dx.doi.org/10.1007/s10640-010-9429-7

Akter, S. (2008). Determinants of willingness to pay for safe drinking water: A case study in Bangladesh. Asian Journal of Water, Environment and Pollution, 5(3), 85-91.

Alpizar, F., Carlsson, F., \& Martinsson, P. (2003). Using choice experiments for non-market valuation. Economic Issues, 8(1), 83-110.

Altaf, A., Jamal, H., \& Whittington, D. (1992). Willingness to pay for water in rural Punjab, Pakistan. UNDP-World Bank Water and Sanitation Program Report Series.

Arrow, K., Solow, R., Portney, P. R., Leamer, E. E., Radner, R., \& Schuman, H. (1993). Report of the National Oceanic and Atmospheric Administration (NOAA) panel on contingent valuation. Federal Register, 58(10), 4601-14.

Atkins, J. P., Burdon, D., \& Allen, J. H. (2007). An application of contingent valuation and decision tree analysis to water quality improvements. Marine Pollution Bulleting, 55, 591-602. http://dx.doi.org/10.1016/j.marpolbul.2007.09.018

Banfi, S., Farsi, M., Filippini, M., \& Jakob, M. (2008). Willingness to pay for energy-saving measures in residential buildings. Energy Economics, 30, 503-516. http://dx.doi.org/10.1016/j.eneco.2006.06.001

Bishop, R. C., \& Heberlein, T. A. (1979). Measuring values of extra market goods: Are indirect measures biased? American Journal of Agricultural Economics, 61, 920-930. http://dx.doi.org/10.2307/3180348

Borchers, A. M., Duke, J. M., \& Parsons, G. R. (2007). Does willingness to pay for green energy differ by source? Energy Policy, 35, 3327-3334. http://dx.doi.org/10.1016/j.enpol.2006.12.009

Brookshire, D. S., Eubanks, L. S., \& Randall, A. (1983). Estimating option prices and existence values for wildlife resources. Land Economics, 59, 1-15. http://dx.doi.org/10.2307/3145871

Brookshire, D., \& Whittington, D. (1993). Water resources issues in the developing countries. Water Resources Research, 29(7), 1883-1888. http://dx.doi.org/10.1029/92WR02988

Calderon, M. M., Camacho, L. D., Carandang. M. G., Dizon, J. T., Rebugio, L. L., \& Tolentino, N. L. (2006). Willingness to pay for improved watershed management: Evidence from Metro Manila, Philippines. Forest Science and Technology, 2, 42-50. http://dx.doi.org/10.1080/21580103.2006.9656298

Carson, R. (2012). Contingent Valuation: A Comprehensive Bibliography and History. United Kingdom: Edward Elgar Publishing.

Carson, R. T. (2003). Contingent valuation: A comprehensive bibliography and history, Cheltenham, UK and Northampton. MA: Edward Elgar.

Carson, R. T., \& Hanemann, M. (2005). ContingentValuation in the Handbook of Environmental Economics (Vol. II). In Maler, K. G., \& Vincent, J. F. (Eds), Valuing Environmental Changes by Elsevier: North Holland.

Casey, J. F., Kahn, J. R., \& Rivas, A. (2006). Willingness to pay for improved water service in Manaus, Amazonas, Brazil. Ecological Economics, 58, 365-372. http://dx.doi.org/10.1016/j.ecolecon.2005.07.016

Champ, P. A., Boyle, K. J., \& Brown T. C. (Eds). (2003). A Primer on Nonmarket Valuation: The Economics of Non-Market Goods and Resources. Boston, USA: Kluwer Academic Publishers. http://dx.doi.org/10.1007/978-94-007-0826-6

Chowdhury, N. T. (1999). Willingness to pay for water in Dhaka slums: A contingent valuation study. International Union for Conservation of Nature and Natural Resources (IUCN).

Ciriacy-Wantrup, S. V. (1947). Capital Returns from Soil Conservation Practices. Journal of Farm Economics, 
29, 1181-96. http://dx.doi.org/10.2307/1232747

Cummings, R. G., Harrison, G. W., \& Rutsrom, E. E. (1995). Homegrown values and hypothetical surveys- Is the Dichotomous choice approach incentive compatible? American Economic Review, 85, 260-266.

Damigos, D., Tourkolias, C., \& Diakoulaki, D. (2009). Households' willingness to pay for safeguarding security of natural gas supply in electricity generation. Energy Policy, 37, 2008-2017. http://dx.doi.org/10.1016/j.enpol.2009.01.042

Davis, R. (1963). The value of outdoor recreation: An economic study of the maine woods (Doctoral dissertation in Economics). Harvard University.

Guha, S. (2007). Valuation of clean water supply by willingness to pay method in a developing nation: A case study in Calcutta, India. Journal of Young Investigators. Retrieved from http://www.jyi.org/.../valuation-of-clean-water-supply-by-willingness-to-pay-method-in-a-developing-natio n-a-case-study-in-calcutta-india

Gunatilake, H., \& Raihan, S. (2013). Willingness to pay for solar powered pump irrigation by rain-fed farmers in Bangladesh. Unpublished report. Manila: ADB.

Gunatilake, H., \& Roland-Holst, D. (2013). Energy Policy Options for Sustainable Development in Bangladesh. ERD Working Paper. Manila: ADB.

Gunatilake, H., Yang, J., Pattanayak, S., \& Berg, C. (2006). Willingness-to-pay and design of water supply and sanitation project: A case study. ERD Technical Note No. 19. Manila: ADB.

Gunatilake, H., Yang, J., Pattanayak, S., \& Choe, K. (2007). Good practices for estimating reliable willingness to pay values in the water and sanitation sector. ERD Technical Note No. 23. Manila: ADB.

Hammack, J., \& Brown, G. (1974). Waterfowl and wetlands: Toward Bioeconomic analysis. Baltimore, MD: Johns Hopkins Press.

Haq, M., Usman, M., \& Ahmad, I. (2007). Household's willingness to pay for safe drinking water: A case study of Abbottabad district. The Pakistan Development Review, 4(46), 1137-1153.

Hensher, D. A., Rose, J. M., \& Greene, W. H. (2005). Applied Choice Analysis: A Primer, First Edition. Cambridge, UK: Cambridge University Press. http://dx.doi.org/10.1017/CBO9780511610356

Islam, A. K. M. N., Kitawaki, H., \& Rahman, M. H. (1994). Willingness to pay for water supply and sanitation. A paper presented at 20th Water, Engineering and Development Centre (WEDC) conference on affordable water supply and sanitation in Colombo, Sri Lanka. Retrieved from http://wedc.lboro.ac.uk/resources/conference/20/Islam.pdf

Jordan, J. L., \& Elnagheeb, A. H. (1993). Willingness to pay for improvements in drinking water quality. Water Resources Research, 29, 237-245. http://dx.doi.org/10.1029/92WR02420

Kanyoka, P., Farolfi, S., \& Morardet, S. (2008). Households' preferences and willingness to pay for multiple water services in rural areas of South Africa: An analysis based on choice modeling. Water South Africa, 34, 715-723.

Komives, K., Foster, V., Halpern, J., \& Wodon, Q. (2005). Water, electricity, and the poor: Who benefits from utility subsidies? Directions in Development Series. Washington, DC: The World Bank. http://dx.doi.org/10.1596/978-0-8213-6342-3

Koss, P., \& Khawaja, M. S. (2001).The value of water supply reliability in California: A contingent valuation study. Water Policy, 3, 165-174. http://dx.doi.org/10.1016/S1366-7017(01)00005-8

Lee, W. S., Yoo, S. H., \& Kim, J. (2013). Measuring the economic benefits of the tap water supply service in urban areas: The case of Korea. Water Resources Management, 27, 619-627. http://dx.doi.org/10.1007/s11269-012-0206-y

MacKerron, G., Egerton, C., Gaskell, C., Parpia, A., \& Mourato, S. (2009). Willingness to pay for Carbon offset certification and co-benefits among (high-)flying young adults in the UK. Energy Policy, 37, 1372-1381. http://dx.doi.org/10.1016/j.enpol.2008.11.023

Mitchell, R. C., \& Carson, R. T. (1989). Using surveys to value public goods: The contingent valuation method. Baltimore, MD: Johns Hopkins University Press.

Mugabi, J., \& Kayaga, S. (2010) Attitudinal and socio-demographic effects on willingness to pay for water services and actual payment behavior. Urban Water Journal, 7, 287-300. 
http://dx.doi.org/10.1080/1573062X.2010.509437

O’Garra, T., Mourato, S., Garrity, L., Schmidt, P., Beerenwinkel, A., Altmann, M., Hart, D., Graesel, C., \& Whitehouse, S. (2007). Is the public willing to pay for hydrogen buses? A comparative study of preferences in four cities. Energy Policy, 35, 3630-3642. http://dx.doi.org/10.1016/j.enpol.2006.12.031

Ramajo-Hernández, J., \& Saz-Salazar, S. (2012). Estimating the non-market benefits of water quality improvement for a case study in Spain: A contingent valuation approach. Environment Science and Policy, 22, 47-59. http://dx.doi.org/10.1016/j.envsci.2012.05.006

Randall, A. (1987). Valuation in a policy context. In D. W. Bromley, (Ed.), Natural resource economics: Policy problems and contemporary analysis. Boston: Kluwer-Nijhoff.

Randall, A., Ives, B. C., \& Eastman, C. (1974). Bidding games for valuation of aesthetic environmental improvements. Journal of Environmental Economics and Management, 1, 132-149. http://dx.doi.org/10.1016/0095-0696(74)90010-2

Samuelson, P. A. (1954). The pure theory of public expenditure. Review of Economics and Statistics, 36, 387-389. http://dx.doi.org/10.2307/1925895

Shogren, J. F. (2005). Experimental methods and valuation. Handbook of Environmental Economics, 2, 969-1027. http://dx.doi.org/10.1016/S1574-0099(05)02019-X

Soto, G., \& Bateman, I. J. (2006). Scope sensitivity in households' willingness to pay for maintained and improved water supplies in a developing world urban area: investigating the influence of baseline supply and income distribution upon stated preferences in Mexico City. Water Resources Research, 42, 1-15.

Stoll, J. R., \& Johnson., L. A. (1984). Concepts of value, non-market valuation, and the case of the whooping crane. Transactions of the Forty-Ninth North American Wildlife and Natural Resources Conference Proceedings, 49, 382-393.

Streimikienè, D., \& Balezentis, A. (2014). Assessment of willingness to pay for renewables in Lithuanian households. Clean Technologies and Environmental Policy, 1-17.

Taneja, G., Pal, B. D., Joshi, P. K., Aggarwal, P. K., \& Tyagi, N. K. (2014). Farmers' Preferences for Climate-Smart Agriculture. IFPRI Discussion Paper 01337. Washington, D.C.: International Food Policy Research Institute.

UNICEF. (2011). Urban water Challenges in Bangladesh. Retrieved from http://www.unicef.org/bangladesh/Urban_water_challenges_in_Bangladesh.pdf

van den Berg, C. S., Pattnayak, S., Yang, J., \& Gunatilake, H. (2006). Getting the assumptions right: Private sector participation transaction design and the poor in Southwest Sri Lanka. Water Supply and Sanitation Board Discussion Paper No. 07. Washington, DC: World Bank.

van Putten, M., Lijesen, M., Özel, T., Vink, N., \& Wevers, H. (2014). Valuing the preferences for micro-generation of renewables by households. Energy, 16(36), 594-605.

Vásquez, W. F., Mozumder, P., Hernández-Arce, J., \& Berrens, R. P. (2009). Willingness to pay for safe drinking water evidence from Parral, Mexico. Journal of Environment Management, 90, 3391-3400. http://dx.doi.org/10.1016/j.jenvman.2009.05.009

Venkatachalam, L. (2006). Factors influencing household willingness to pay (WTP) for drinking water in peri-urban areas: A case study in the Indian context. Water Policy, 8(5), 461-473. http://dx.doi.org/10.2166/wp.2006.055

Wang, H., Xie, J., \& Li, H. (2010). Water pricing with household surveys: A study of acceptability and willingness to pay in Chongqing, China. China Economic Review, 21, 136-149. http://dx.doi.org/10.1016/j.chieco.2009.12.001

Whittington, D. (1998). Guidelines for conducting willingness-to-pay studies for improved water services in developing countries. WASH Technical Report No. 56, Water and Sanitation for Health Project. Washington, DC: US Agency for International Development.

Whittington, D. (2002). Behavioural studies of the domestic demand for water services in Africa: A reply to Stephen Merrett. Water Policy, 4, 83-88. http://dx.doi.org/10.1016/S1366-7017(02)00022-3

Whittington, D. (2003). Municipal water pricing and tariff design: A reform agenda for South Asia. Water Policy, 5(1), 61-76.

Whittington, D., Pattanayak, S. K., Yang, J. C., \& Kumar, B. (2002). Do households want improved piped water 


\begin{tabular}{|c|c|}
\hline services? & Evidence \\
\hline
\end{tabular}
http://dx.doi.org/10.1016/S1366-7017(02)00040-5

Woo, C. K., Shiu, A., Cheng, Y. S., Li, R., Ho, T., Horowitz, I., \& Wang, J. (2014). Residential Willingness-to-Pay for Reducing Coal-Fired Generation's Emissions in Hong Kong. The Electricity Journal, 27(3), 50-66. http://dx.doi.org/10.1016/j.tej.2014.03.009

Yang, J., Pattanayak, S. K., Johnson, R., Mansfield, C., van den Berg, C., \& Jones, K. (2006). Unpackaging Demand for Urban Water Supply: Evidence from Conjoint Surveys in Sri Lanka. World Bank Policy Research Paper 3817. World Bank.

\section{Copyrights}

Copyright for this article is retained by the author(s), with first publication rights granted to the journal.

This is an open-access article distributed under the terms and conditions of the Creative Commons Attribution license (http://creativecommons.org/licenses/by/3.0/). 